\title{
Export Competitiveness of Indonesian Coffee in Germany
}

\author{
Fadhlan Zuhdi ${ }^{1 *}$, Rachmiwati Yusuf ${ }^{2}$ \\ Riau Agricultural Technology Assessment Center \\ Received: 25 September 2020; Revised: 8 March 2021; Accepted: 8 October 2021
}

\begin{abstract}
Coffee has been one of the mainstay products for Indonesia's exports to Germany since the last time and the frequency continues to increase. This reflects that Germany's need for coffee continues to grow. This study aims to measure the position of Indonesia's coffee export competitiveness in Germany. The method used in this research are Revealed Comparative Advantage (RCA) and Constant Market Share (CMS). The results showed that Indonesia's coffee exports were not competitive in Germany and had a downward trend. The export performance of Indonesian coffee in Germany also shows a downward trend in each period. Several things that need to be improved so that the competitiveness and performance of Indonesia's exports can increase is by disseminating information regarding the use of cultivation technology to increase the productivity of Indonesian coffee.
\end{abstract}

Keywords: coffee; cms; export; trade; rca

\section{How to cite:}

Zuhdi, F., \& Yusuf, R. (2021). Export Competitiveness of Indonesian Coffee In Germany. Habitat, 32(3), 130-140. https://doi.org/10.21776/ub.habitat.2021.032.3.15

\section{Introduction}

The Federal Republic of Germany is one of the countries in Central Europe which has a long history with Indonesia. Since 1952, diplomatic relations between Indonesia and Germany have officially started. These diplomatic relations make Indonesia a country outside of Europe which has the longest bilateral relationship with Germany to date. The closeness of bilateral relations between Indonesia and Germany has reached a new history, in 2012 the document The German-Indonesian Joint Declaration for a Comprehensive was agreed. Partnership: Shaping Globalization and Sharing Responsibility by each head of state. The document agrees on $5+3$ areas of cooperation that the two countries need to develop, which includes: Economic Cooperation (Trade and Investment), Education, Research and Technology, Health, Defense Industry, Food Security, Food Energy, and Transportation. Furthermore, the two countries are also committed to continuing to develop positive, constructive bilateral relations and respect for each other's sovereignty (Ministry of Foreign Affairs, 2020)

\footnotetext{
*) Correspondence author

E-mail: fadhlanzuhdi21@gmail.com

Telp: +62-822-44525492
}

One of the agreements between Indonesia and Germany based on the declaration document is the development in the field of Economic Cooperation (Trade and Investment). A component of particular concern is trading between the two countries through export and import schemes. Based on data Central Statistic Agency of Indonesia (2020), Germany is ranked seventh as Indonesia's largest export destination after China, the United States, Japan, Singapore, South Korea, and Taiwan. As Indonesia's main trading partner, Germany has carried out many import activities from Indonesia. Indonesia's superior export products to Germany include agricultural commodities, electronic equipment, clothing, and mechanical machines (Ministry of Foreign Affairs, 2020).

Coffee is an Indonesian agricultural commodity that has been excellent in Germany for quite a long time. Coffee has been producing by more than 50 countries in the world (Petit, 2007), and Indonesia is one of the largest coffee producers among these countries. Torok et al. (2018) stated that world coffee production has increased by up to $65 \%$ from 1995 to 2015 and one of the triggering factors is the increase in Vietnam's coffee production which reached $600 \%$ in the early 2000s and became the second-largest exporter in the world (Nguyen, 2015). This condition causes coffee export competition to 
become more open than initially dominated by coffee producers such as Brazil, Colombia, and Indonesia.

As one of the largest coffee exporting countries in the world, Indonesia has a great opportunity to increase the country's income from export activities. This can also integrate Indonesia with other countries in the global economy (Hong, 2016). Therefore, this opportunity must be optimized by increasing the volume of Indonesian coffee exports to potential export countries, especially coffee is the second most important commodity in the world after oil (Pascucci, 2018). Analysis of the competitiveness of Indonesian coffee exports in potential importing countries such as Germany, where this analysis also involves competing for exporting countries of Indonesia as a comparison can be used as a basis for implementing an export strategy. An assessment of the performance of Indonesian coffee exports also needs to be done so that it is known what elements affect the performance of Indonesian coffee exports. Based on this, this study aims to measure the competitiveness and performance of Indonesian coffee exports in Germany in the context of implementing the cooperation development agreement in the field of Economic Cooperation.

\section{Theoritical Underpinning}

In the last few decades, the issue of fair trade has become an issue that has significantly increased and deserves further attention related to the value of sustainability and ethical consumption in society (Ribeiro-Duthie et al., 2021). Fair trade is a forum that aims to improve the living standards of the poor by giving freedom to producers to manage the products they produce (Dragusanu et al., 2014). Developing countries that are dominated by people with lower middle income have the potential to develop export concentrations, sectors and markets (Osakwe et al., 2018). Governments in developing countries have begun to initiate policies and programs in the context of accelerating economic growth through the agricultural sector (Nugroho, 2021).

Based on the developing theory, globalization and global trade have a strong influence on sustainability issues (Rathgens et al., 2020). Exports have a positive impact on a country's economic growth as reflected in the increase of trade balance, job creation and living standards as well as improving the economic welfare of the community (Freeman \& Styles, 2014; Mansion \& Bausch, 2020).

Some commodities such as coffee are produced in a different place from the place where they are produced (Yu et al., 2013). Coffee is a commodity that gets a lot of attention at the global level because coffee exports have a positive and significant reflection on economic growth (Yifru, 2015). The coffee trade has gained traction in developing countries such as South Africa and China. However, the high price of coffee has led to market inefficiencies which in turn lower profits (Fridell, 2014).

Based on this, Indonesia, which is a developing country, can use exports as a vector to improve the country's economy. However, given the issue of market inefficiency and declining coffee trading profits, further discussion is needed about the competitiveness of Indonesian coffee exports in certain markets (Germany) to map the position and potential of Indonesia's coffee trade.

\section{Material and Methods}

This study used secondary time series data for a period of 17 years (2002-2019) compiled from Trade Map and United Nations Comtrade Database (UN Comtrade). The data that has been collected, then grouped into three time periods to make it easier to carried out the analysis. Each period has a span of six years, namely period I (2002-2007), period II (2008-2013), and period III (2014-2019). The object of this research is a coffee commodity with the code Harmonized System (HS) 0901 in which there are four largest exporting countries in the world which used as research subjects, namely Indonesia, Brazil, Vietnam, and Colombia. The importing countries that were the subject of the study were Germany, which involved United Kingdom (UK) and Italy as comparisons. The research method used in this research is quantitative descriptive with the use of Revealed Comparative Advantage (RCA) and Constant Market Share (CMS) as analytical tools to measure the competitiveness of Indonesian coffee exports and competitors in Germany.

Revealed Comparative Advantage (RCA) used to analyze the competitiveness of Indonesian coffee exports and competitors in Germany. RCA used in many studies to measure international competitiveness (Bojnec \& Fertő, 2017; Kuldilok et al., 2013). Also, Benesova et al. (2017) and Granabetter (2016) stated that RCA is a dynamic measurement method used in many studies to measure the comparative advantage of various 
sectors and the main one is the agricultural sector. The concept of RCA itself is the ratio between the market share of a country's product in the world market and the share of a country's exports to total world exports. Mathematically RCA can be calculated using the following formula (Frija et al., 2017):

$$
R C A=\frac{\left(\frac{X k i}{X t i}\right)}{\left(\frac{W k}{W t}\right)}
$$

where: $\mathrm{X}$ - represents exports; $\mathrm{i}$ - is a country; $\mathrm{k}-$ is a commodity; and $\mathrm{t}-$ is total.

The RCA index varies between 0 and infinity; if the RCA value index is $>1$, then there is a comparative advantage to a product and if the RCA value index $<1$, then there is no comparative advantage to a product. The higher the RCA value, the higher a competitive commodity.
Constant Market Share (CMS) is an empirical analysis tool that is widely used to see a country's export performance and see structural changes in international trade (Batista, 2008; Capobianco-Uriarte et al., 2017; Fontoura \& Serôdio, 2017). In this study, CMS is used as a tool to analyze the sources of growth in coffee exports in Indonesia and competing countries. The growth of a country's exports can be described in four effects, namely: the effect of world demand, the effect of commodity composition, the effect of market distribution, and the effect of competitiveness. This explains the difference between actual export growth and export growth calculated with the assumption that each export flow grows according to the import market, namely the market share of each country for each commodity in each market remains constant (Taj, 2019). Furthermore Kamal et al. (2020) stated that to describe the actual export growth in the CMS analysis, the following formula is used:

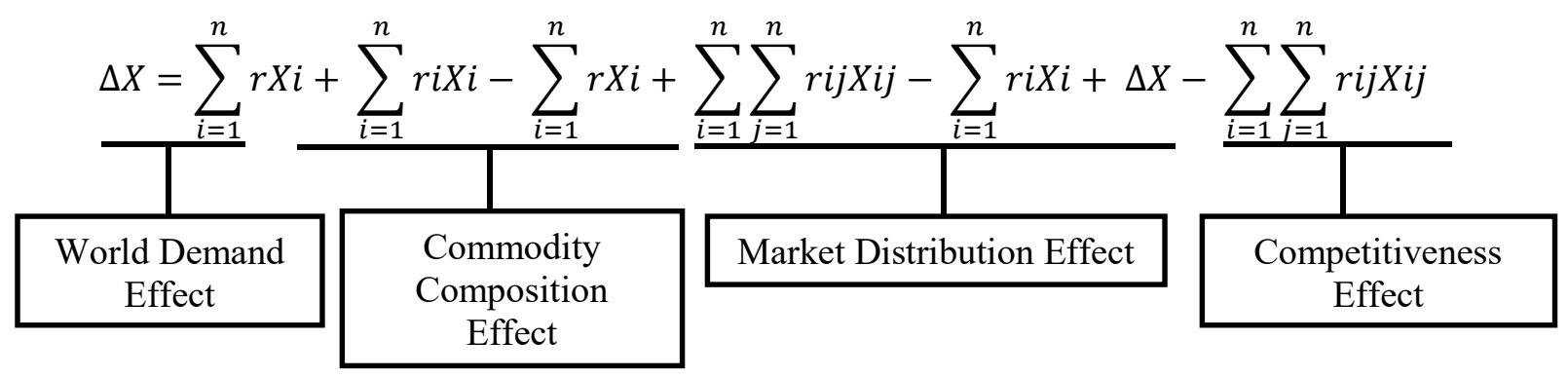

where: $\Delta \mathrm{X}$ - represents actual change in country's exports; $\mathrm{r}$ - represents percentage increase in total world exports; ri - represents percentage increase in world exports of commodity I; rij - represents percentage increase in world exports of commodity $\mathrm{i}$ to region $\mathrm{j}$; $\mathrm{Xi}$ - represents Indonesia's exports of commodity $i$ to rest of the world; and Xij - represents Indonesia's exports of commodity $\mathrm{i}$ to region $\mathrm{j}$.

The effects that interpret world growth can be described as follows:

1) The effect of world demand, namely to measure the impact of developing world demand on the export growth of exporting countries

2) The effect of commodity composition, which reflects the contribution and changes in the growth rate of a country's commodity exports compared to the growth in world average exports.

3) Market distribution effect, which reflects the export response of the exporting country to the increasing demand of the importing country.

4) Competitiveness effect, which reflects the impact of other factors including changes in relative prices, government policies, and non-price factors.

\section{Result and Discussion}

The market share of Indonesian coffee exports to Germany during the 2002-2019 period had a positive average of $4.80 \%$. This number is still relatively small when compared to several other exporting countries such as Brazil, Vietnam, and Colombia, which each have an average market share value in Germany of $30.16 \%, 13.79 \%$, and $5.70 \%$. Based on these calculations, the export market share for coffee by these four exporting countries has dominated the export market share for Germany coffee by $54.45 \%$. This reflects that Indonesia is an important coffee exporting country for Germany, but it does not rule out the possibility that Indonesia's market share in Germany could also decline if efforts to increase 
exports are not made. The export share of each exporting country to Germany as a comparison in each period is presented in Figure 1.

Indonesia's coffee exports to Germany during the same period had an average export share of $12.5 \%$ of the total Indonesian coffee exports to the world. When compared with other exporting countries, the share of Indonesian coffee exports to Germany is still higher than the share of Colombian coffee exports to the same country with only a value of $9.88 \%$, while Brazil and Vietnam respectively have export shares of $19.82 \%$ and $14.20 \%$. The high share of Brazilian coffee exports is not surprising considering that Brazil almost monopolized the coffee export market in the world in early 2000 (Jarvis, 2012). However, Vietnam is a new phenomenon with the rapid growth of coffee exports in the world. There is an interesting point based on the export share data, when viewed from the share of Indonesian and Colombian coffee exports in Germany, the share of Colombian coffee exports is one level higher than the share of Indonesian coffee exports. This reflects that the overall export volume of Indonesian coffee is lagging behind the total export volume of Colombian coffee. Based on data compiled from FAOSTAT (2020), the average production of Indonesian coffee in the 2002-2019 period was 672774 tons per year with an average growth of $1.59 \%$. Meanwhile, the average production owned by Colombia in the same period was 671015 tons with an average growth rate of $1.61 \%$. Production growth between the two countries is not much different and only has a difference of $0.02 \%$, even in 2018 Indonesian coffee production was greater than 1 683 tons when compared to Colombian coffee production. This indicates that Indonesia's domestic coffee consumption is far greater than that of Colombia's domestic coffee so that the volume of Indonesian coffee that can be exported is relatively smaller. This is confirmed by calculations that have been done in which the average domestic coffee consumption in Indonesia is 269726 tons or $40.42 \%$ of total production, while Colombia's domestic consumption is only 81130 tons or $11.18 \%$ of total production. Furthermore, the average number of production and the average number of exports of coffee in the exporting country in each period is presented in Figure 2.

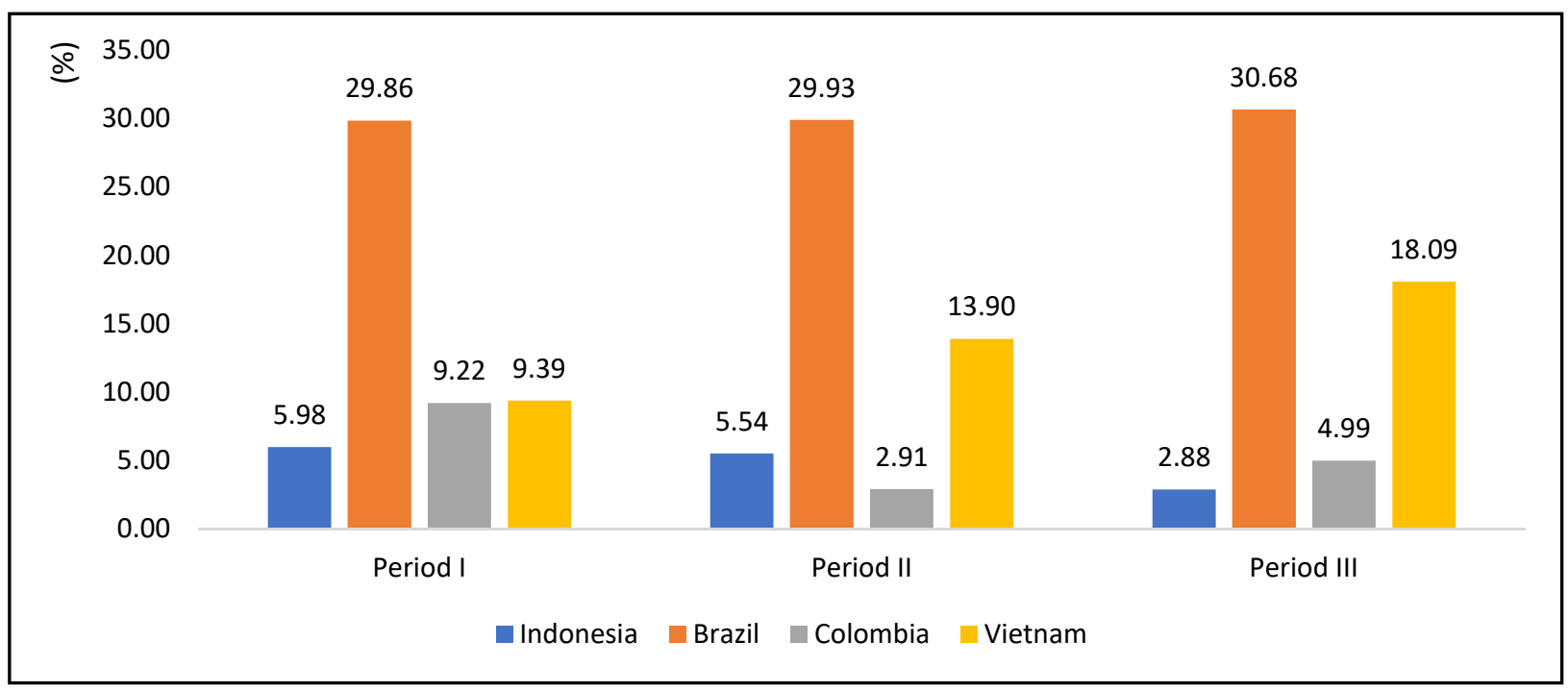

Figure 1. Exporting countries export share to Germany (\%). (Trade Map, author's calculations, 2020) 


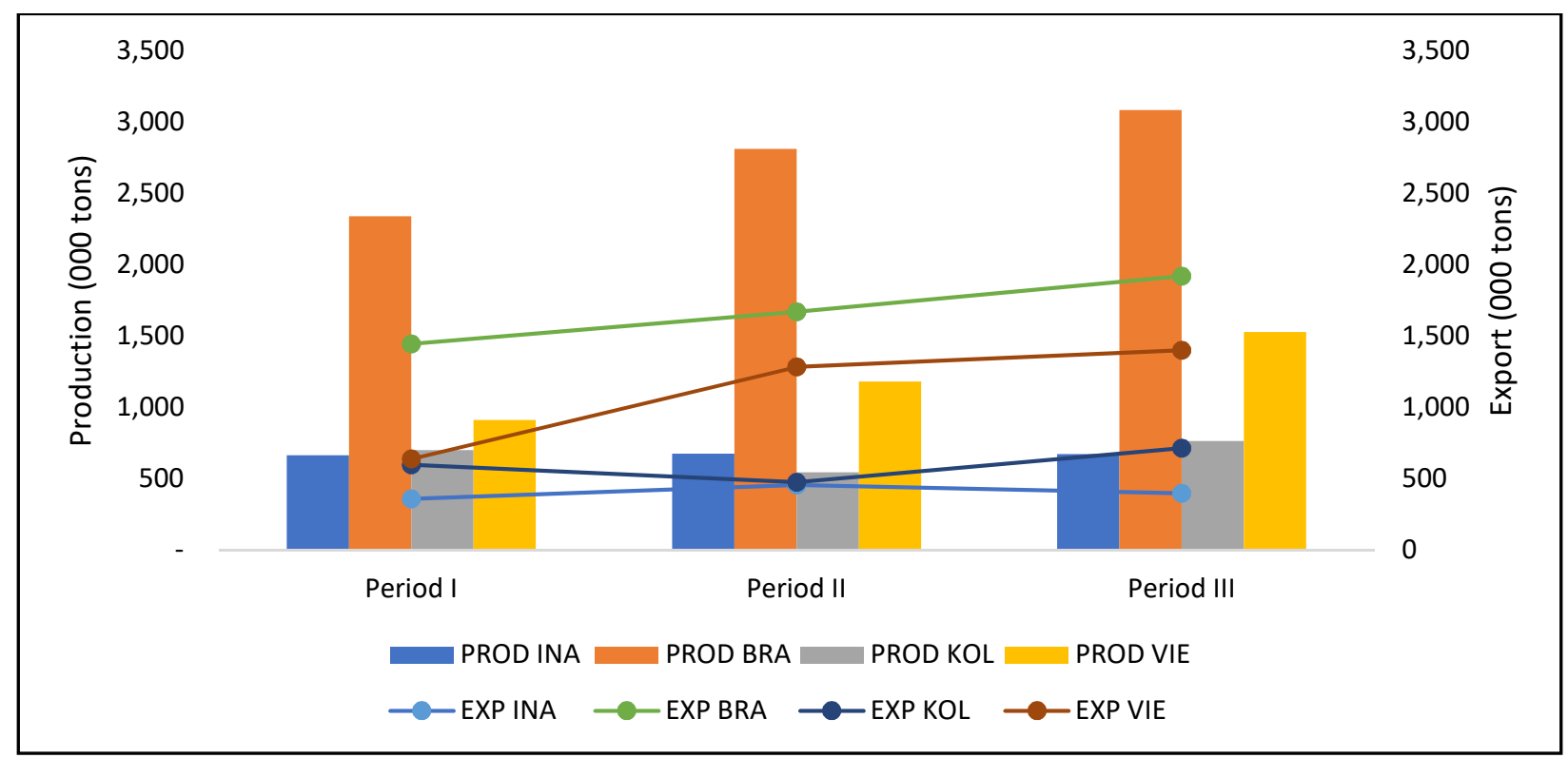

Figure 2. Production (PROD) and export coffee average (EXP) to exporting countries (INA - Indonesia; BRA - Brazil; KOL - Colombia; VIE - Vietnam). (Trade Map, author's calculations, 2020)

Several factors that greatly influenced the increase in Indonesian coffee exports were domestic coffee production and consumption. However, Indonesia's coffee exports to Germany, which are relatively low compared to other exporters, are also thought to be influenced by coffee land area and coffee productivity. Based on data that has been compiled and processed from FAOSTAT, the area of Indonesian coffee in the 2001-2019 period has decreased by an average of $0.30 \%$ or $0.97 \%$ better than the average decline in coffee land area in Brazil which reached an average of $1.27 \%$. In contrast to Indonesia and Brazil, Colombia and Vietnam did not experience a decrease in coffee land area but an increase. The average increase in the coffee area of Colombia and Vietnam was $0.68 \%$ and $1.61 \%$, respectively. However, when viewed from the productivity side, all of these exporting countries experienced an increase in average productivity with Indonesia as the exporting country having the lowest increase in exporters, namely $0.52 \%$, while Brazil, Colombia, and Vietnam experienced an increase in average productivity with their respective values by $1.28 \%, 0.88 \%$, and $2.18 \%$. Vietnam became a country that had the highest average productivity increase compared to other countries and this had a very positive impact on the increase in Vietnam's coffee production which increased by an average of $4.53 \%$. The average growth in land area and productivity of exporting countries are presented in Figure 3. 


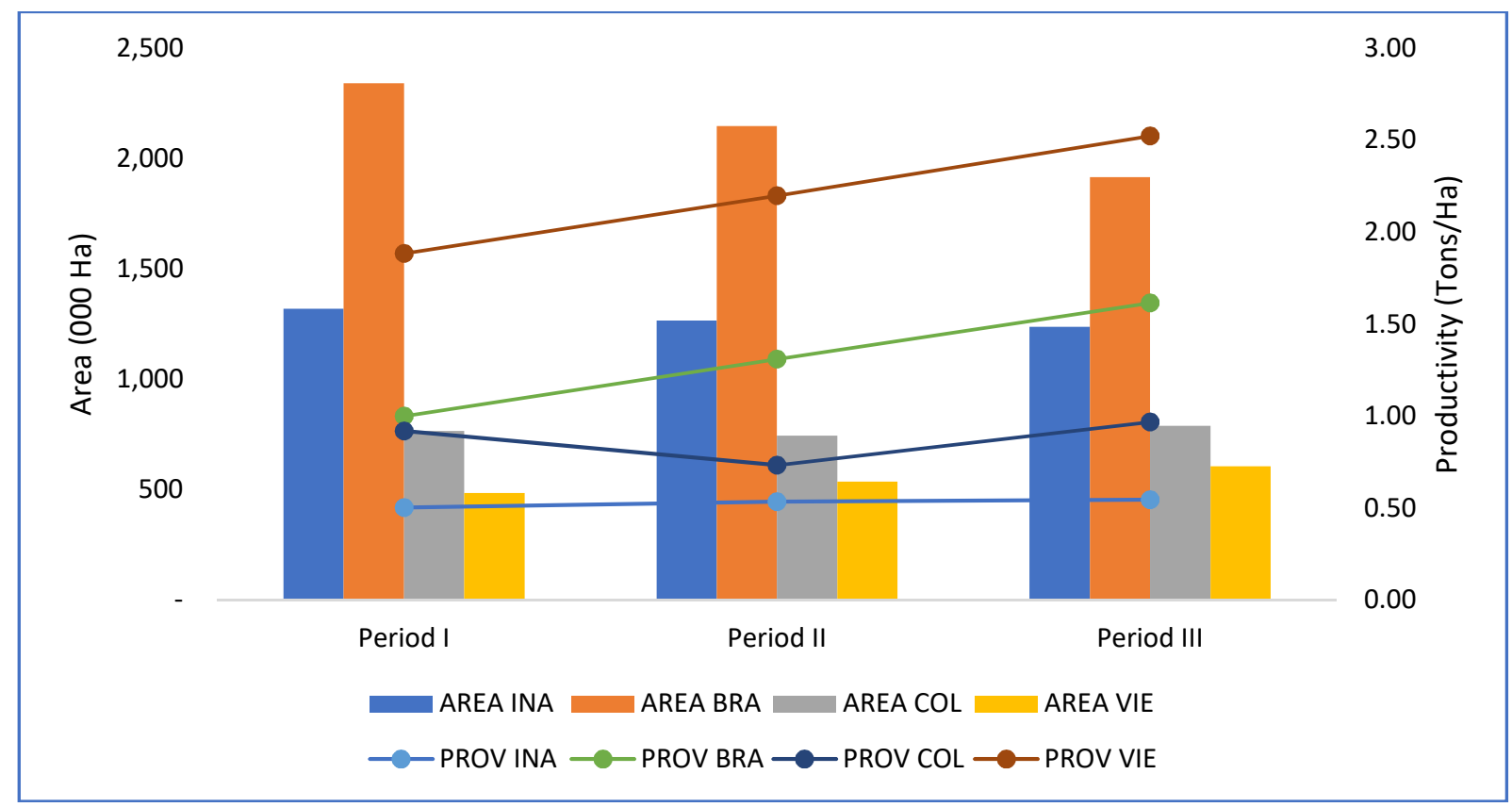

Figure 3. The growth rate of land area (AREA) and productivity (PROV) of exporting countries (INA Indonesia; BRA - Brazil; KOL - Colombia; VIE - Vietnam). (Trade Map, author's calculations, 2020)

The competitiveness of coffee exports from exporting countries to Germany is carried out using the Revealed Comparative Advantage (RCA) method. Based on the results of RCA calculations, Indonesia is an exporting country that can be said to have no export competitiveness to Germany because it has an average value of RCA $<1$ with a value of 0.45 . Other exporting countries such as Brazil, Colombia, and Vietnam have an average RCA value $>1$ and it can be said that these three countries have export competitiveness in Germany where each country has an average RCA value of 3.10, 4.66, and 2.12. However, if we look at the RCA value per period, all exporting countries experienced a decrease in the average RCA with Vietnam as the exporting country experiencing the largest decline with a decrease in value of -34.07 . This indicates that coffee exports from exporting countries to Germany are increasingly not selling so slowly each exporting country shifts its export market to other countries. Another thing that can be used as an indication is that Germany is slowly no longer depending on coffee imports from these four exporting countries and is opening up coffee imports from other countries. Countries from Africa such as Ethiopia, Burundi, and Uganda which make the coffee export sector an important sector for their economies (Nsabimana \& Tirkaso, 2020). This has caused the four export countries to become under pressure and seek new export markets. Simultaneously, this is in line with the positive growth in the volume of coffee exports from other countries to Germany such as Ethiopia, Honduras, and India, especially in period II with an average growth of $26.87 \%, 7.87 \%$, and $9.55 \%$ respectively. Furthermore, the average RCA value of exporting countries in the Germany market is presented and the development of the coffee export volume of Ethiopia, Honduras, and India to Germany is presented in Table 1 and Table 2.

Table 1. Average RCA value of exporting countries in Germany. (Trade Map, author's calculations, 2020)

\begin{tabular}{lrrrr}
\hline \multicolumn{1}{c}{ Period } & Indonesia & Brazil & Colombia & Vietnam \\
\hline Period I & 0.59 & 4.00 & 8.28 & 2.94 \\
Period II & 0.49 & 3.05 & 1.76 & 2.15 \\
Period III & 0.27 & 2.59 & 2.92 & 1.26 \\
Period I - Period II & -0.10 & -0.95 & -6.52 & -0.79 \\
Period II - Period III & -0.22 & -0.46 & 1.16 & -0.89 \\
\hline Total average & 0.45 & 3.10 & 4.66 & 2.12 \\
\hline
\end{tabular}


Table 2. The development of the coffee export volume of Ethiopia, Honduras and India to Germany. (Trade Map, author's calculations, 2020)

\begin{tabular}{lrrrrrr}
\hline & \multicolumn{2}{c}{$\begin{array}{c}\text { Period I } \\
\text { Country }\end{array}$} & \multicolumn{2}{c}{$\begin{array}{c}\text { Period II } \\
(2002-2007)\end{array}$} & \multicolumn{2}{c}{$\begin{array}{c}\text { Period III } \\
(2014-2019)\end{array}$} \\
\cline { 2 - 7 } & $\begin{array}{r}\text { Export } \\
\text { average } \\
\text { (tons) }\end{array}$ & $\begin{array}{r}\text { Market } \\
\text { share (\%) }\end{array}$ & $\begin{array}{r}\text { Export } \\
\text { average } \\
\text { (tons) }\end{array}$ & $\begin{array}{r}\text { Market } \\
\text { share (\%) }\end{array}$ & $\begin{array}{r}\text { Export } \\
\text { Average } \\
\text { (tons) }\end{array}$ & $\begin{array}{r}\text { Market } \\
\text { share (\%) }\end{array}$ \\
\hline Ethiopia & 5213 & 5.28 & 41639 & 5.47 & 34498 & 2.15 \\
Honduras & 53637 & 3.67 & 69114 & 6.01 & 88824 & 1.95 \\
India & 20664 & 2.91 & 22492 & 7.47 & 31551 & 2.65 \\
\hline
\end{tabular}

RCA analysis is also carried out to see the competitiveness of coffee exports of exporting countries in other importing countries, namely English and Italian. Based on the results of RCA calculations, it can be seen that the average Indonesian RCA value for the UK and Italian markets are not competitive and is even worse than the average Indonesian RCA value in the Germany market. Not only Indonesia, Brazil, which is the largest coffee exporter in the world, also do not have the competitiveness of coffee exports in the UK market because it only has an average RCA value of 0.26 . This indicates that Indonesia and Brazil are not focusing their coffee exports to the UK but other countries with more potential. The value of Indonesia's RCA in the Italian market is also no better than the value of Indonesia's RCA in the German market. This again indicates that Italy is not the main export destination market for Indonesian coffee in Europe, even though Italy is one of the largest coffee importing countries in Europe where imported coffee will be re-exported in the form of coffee roasts (Morris, 2010). Furthermore, the average RCA values for Indonesia in the UK and Italian markets are presented in Table 3 and Table 4.

Table 3. Average RCA value of exporting countries in United Kingdom. (Trade Map, author's calculations, 2020)

\begin{tabular}{lrrrr}
\hline \multicolumn{1}{c}{ Period } & Indonesia & Brazil & Colombia & Vietnam \\
\hline Period I & 0.12 & 0.22 & 1.63 & 1.48 \\
Period II & 0.14 & 0.25 & 1.13 & 0.48 \\
Period III & 0.14 & 0.32 & 0.99 & 0.23 \\
Periode I - Periode II & 0.02 & 0.03 & -0.50 & -1.00 \\
Periode II - Periode III & 0.00 & 0.07 & -0.14 & -0.25 \\
\hline Total average & 0.13 & 0.26 & 1.25 & 0.73 \\
\hline
\end{tabular}

Table 4. Average RCA value of exporting countries in Italy. (Trade Map, author's calculations, 2020)

\begin{tabular}{lrrrr}
\hline \multicolumn{1}{c}{ Period } & Indonesia & Brazil & Colombia & Vietnam \\
\hline Period I & 0.24 & 1.97 & 1.81 & 1.56 \\
Period II & 0.23 & 1.49 & 0.58 & 1.23 \\
Period III & 0.24 & 1.37 & 1.00 & 0.68 \\
Period I - Period II & -0.01 & -0.48 & -1.23 & -0.33 \\
Period II - Period III & 0.01 & -0.12 & 0.42 & -0.55 \\
\hline Total average & 0.236 & 1.61 & 1.13 & 1.16 \\
\hline
\end{tabular}

Indonesia's low export competitiveness in the Germany, British, and Italian markets does not always reflect that Indonesian coffee cannot compete in these importing countries. The RCA calculation measures the extent to which Indonesian coffee exports to importing countries can contribute relatively to Indonesia's total exports to the world. The difference in views of each exporting country regarding potential export markets can also be used as a basis for focusing on export destinations. Based on the data presented, it can be seen that Germany, UK, and Italy are potential export markets, especially in the European region. This is based on the fact that from 2002 to 2019 it was noted that coffee imports in the three countries had always increased. The 
increase in imports indicates that the demand for coffee in importing countries continues to grow. The following shows the average development of
German, British, and Italian coffee imports for each time as shown in Figure 4.

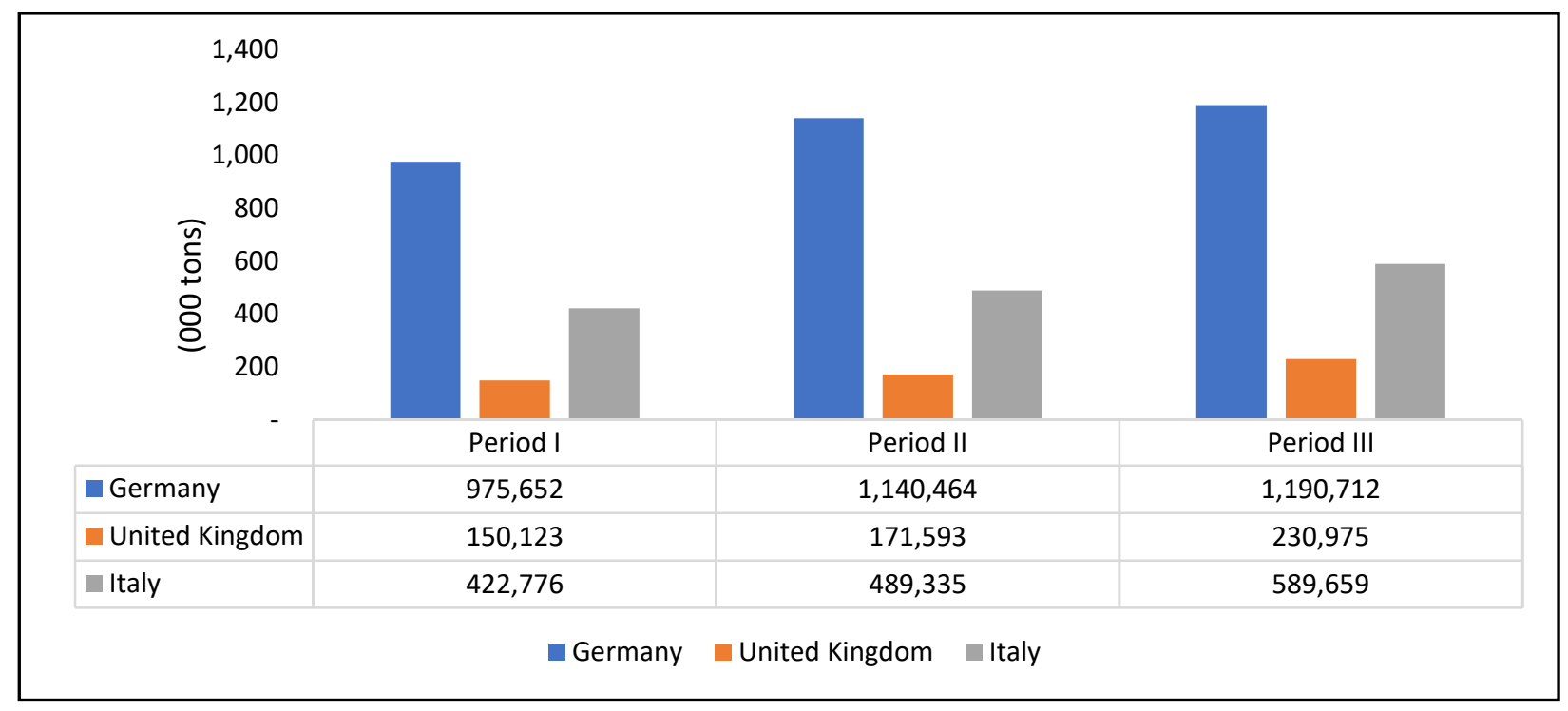

Figure 4. The development of average coffee imports in Germany, UK and Italy (tons). (Trade Map, author's calculations, 2020)

Further analysis to see the export performance of a country is carried out using the Constant Market Share (CMS) method. Based on the results of the CMS calculation in the German market which is presented in Table 5, it can be seen in periods I and II that the effect of competitiveness is a factor affecting the performance of Indonesia's coffee exports to Germany. In the same period, Brazil as the largest coffee exporter in the world also harmed competitiveness but with a lower value. This indicates that Indonesia and Brazil had problems with the export competitiveness factor in Germany in the early periods (I and II). Some of the things that affect the low competitiveness are the superiority of the quality of coffee products and also the coffee prices of exporting countries that do not meet the prices demanded by Germany. However, in period III, Indonesia and Brazil succeeded in improving the competitiveness of coffee products exported to Germany, which was confirmed by the CMS calculation in period III which was positive at 2.45 and 0.10 , respectively. It is different from Vietnam wherein period I, the effect of competitiveness had a very high negative value, namely -90.27 , but it slowly started to decrease to -1.27 in period III. This illustrates that in the early period Vietnam focused more on increasing coffee production and did not simultaneously improve the quality of coffee produced. But slowly, Vietnam was able to improve the quality of its coffee until period III had succeeded in reducing the value of the competitiveness effect to 89 .

The effect of world demand directly put pressure on coffee exporting countries, causing a decline in the performance of coffee exports to Germany. This is confirmed by the results of the CMS analysis which shows a decrease in the value of the effect of world demand in each period for each exporting country. The decline in this value indicates that coffee consumption in the world continues to increase and has an impact on the coffee demand in the world. The high interest in coffee, on the one hand, is beneficial for exporting countries but on the other hand, it will also force exporting countries to be able to produce more coffee to meet world market demand. Furthermore, the effect of commodity composition is also an important concern in analyzing the performance of Indonesian coffee exports in the Germany market. In the period I, Indonesian and Vietnamese coffee became one of the coffee that was in great demand by the German people, which was reflected in the high value of the effect of commodity composition on the CMS calculation, which was respectively 11.37 and 12.19. However, this positive value went down until it reached a negative value in period III, which indicates that German people's interest in Indonesian coffee has waned. The growth in exports from other exporting countries to 
Germany is thought to be one of the reasons why Indonesian and Vietnamese coffee are no longer in great demand by the German people.

The influence of market distribution is the only influence that has a fluctuating CMS value. The effect of market distribution reflects the export response of the exporting country to the increase in demand that occurs in the importing country. This makes coffee exports difficult to predict given that export demand is very dynamic.
In periods I and II, the distribution effect of the Indonesian market in Germany has a positive value and tends to be stable, however, in period III the effect of market distribution becomes negative. This also happened to Brazil, Colombia, and Vietnam, but with different values and scenarios. Furthermore, the CMS value for each exporting country in the Germany market can be seen in Table 5.

Table 5. Constant Market Share (CMS) value of Indonesian, Brazilian, Colombian and Vietnamese coffee in Germany. (Trade Map, author's calculations, 2020)

\begin{tabular}{lllll}
\hline \multicolumn{1}{c}{ Period } & Indonesia & Brazil & Colombia & Vietnam \\
\hline Period I & & & & \\
$\quad$ World Demand Effect & 12.68 & 18.72 & 16.54 & 21.73 \\
$\quad$ Commodity Composition Effect & 11.37 & 0.98 & -0.67 & 12.19 \\
$\quad$ Market Distribution Effect & 4.33 & 0.99 & -5.98 & 86.56 \\
$\quad \begin{array}{l}\text { Competitiveness Effect } \\
\text { Period II }\end{array}$ & -10.39 & -1.56 & 0.00 & -90.27 \\
$\quad$ World Demand Effect & & & & \\
$\quad$ Commodity Composition Effect & 9.83 & 8.97 & 13.40 & 19.05 \\
$\quad$ Market Distribution Effect & 3.43 & 0.45 & -9.24 & -10.94 \\
$\quad$ Competitiveness Effect & 4.63 & -1.49 & -5.14 & -0.74 \\
Period III & -6.67 & -0.39 & -0.06 & -2.01 \\
$\quad$ World Demand Effect & & & & \\
$\quad$ Commodity Composition Effect & -0.92 & -0.68 & -4.66 & 16.05 \\
$\quad$ Market Distribution Effect & -1.99 & 1.47 & 8.89 & -14.56 \\
$\quad$ Competitiveness Effect & -5.56 & -0.03 & 4.44 & 0.96 \\
\hline
\end{tabular}

\section{Conclusion}

Indonesian coffee exports in the Germany market at each period do not have good competitiveness which is reflected in the average value of Indonesia's RCA which is always negative. This does not always reflect that Indonesian coffee cannot compete in the Germany market, but the focus of Indonesian coffee exports is not entirely in Germany but also for other countries. Along with the increasing demand for coffee imports in importing countries, especially in Europe, such as Germany, United Kingdom, and Italy, the coffee exports to these countries are very potential. The periodic performance of Indonesia's coffee exports to Germany has shown poor performance. This is reflected in the CMS calculation which tends to decrease in each calculated indicator. The downward trend in export performance is indicated by the increasing number of other exporting countries, both from Africa and America, which have entered the coffee export market to Germany. This directly depresses the market share of exporting countries such as Indonesia, Brazil, Colombia, and Vietnam which in turn has an impact on shifting the volume of exports to the Germany market in a negative direction. Furthermore, by knowing the potential export market for coffee, the government is expected to be able to develop a strategy to increase exports to that potential market. One of the strategies that the government can undertake in general at this time, among others, is to increase production through increasing productivity through the dissemination of cultivation technology and technology packages to coffee producer.

\section{References}

Batista, J. C. (2008). Competition between Brazil and other exporting countries in the US import market: A new extension of constant-market-shares analysis. Applied Economics, 40(19), 2477-2487. https://doi.org/10.1080/000368406009702 03 
Benesova, I., Maitah, M., Smutka, L., Tomsik, K., \& Ishchukova, N. (2017). Perspectives of the Russian Agricultural Exports in terms of Comparative Advantage. Agricultural Economics (Czech Republic), 63(7), 318330. https://doi.org/10.17221/344/2015AGRICECON

Bojnec, Š., \& Fertö, I. (2017). The Duration of Global Agri-Food Export Competitiveness. British Food Journal, 119(6), 1378-1393. https://doi.org/10.1108/BFJ-07-2016-0302

Capobianco-Uriarte, M., Aparicio, J., \& De PabloValenciano, J. (2017). Analysis of Spain's Competitiveness in the European Tomato Market: An Application of the Constant Market Share Method. Spanish Journal of Agricultural Research, 15(3), 1-13. https://doi.org/10.5424/sjar/201715310629

Central Statistic Agency of Indonesia. (2020). Ekspor Kopi Menurut Negara Tujuan Utama.

https://www.bps.go.id/statictable/2014/09/

08/1014/ekspor-kopi-menurut-negara-

tujuan-utama-2000-2019.html

Dragusanu, R., Giovannucci, D., \& Nunn, N. (2014). The economics of fair trade. Journal of Economic Perspectives, 28(3), 217-236.

https://doi.org/10.1257/jep.28.3.217

FAOSTAT. (2020). Crops Statistics. Food and Agriculture Organization of the United Nations.

http://www.fao.org/faostat/en/\#data/QC

Fontoura, M. P., \& Serôdio, P. (2017). The export performance of the $2004 \mathrm{EU}$ enlargement economies since the 1990s: a constant market share analysis. International Advances in Economic Research, 23(2), 161-174. https://doi.org/10.1007/s11294017-9630-3

Freeman, J., \& Styles, C. (2014). Does location matter to export performance? International Marketing Review, 31(2), 181-208. https://doi.org/10.1108/IMR-022013-0039

Fridell, G. (2014). Fair trade Slippages and Vietnam gaps: The ideological fantasies of Fair Trade Coffee. Third World Quarterly, 35(7), 1179-1194. https://doi.org/10.1080/01436597.2014.92
6108

Frija, A., Dhehibi, B., Salah, M. Ben, \& AwHassan, A. (2017). Competitive advantage of GCC date palm sector in the international market: market shares, revealed comparative advantages, and trade balance indexes. International Journal of Marketing Studies, $9(6), \quad 1-13$. https://doi.org/10.5539/ijms.v9n6p1

Granabetter, D. (2016). Revealed comparative advantage index: an analysis of export trade in the Austrian district of Burgenland. Review of Innovation and Competitiveness, 2(2), 97-114. www.phasing-out.at

Hong, T. T. K. (2016). Effects of Exchange Rate and World Prices on Export Price of Vietnamese Coffee. International Journal of Economics and Financial Issues, 6(4), $1756-1759$.

Jarvis, L. S. (2012). The Welfare Implications of Brazil's Coffee Export Price Subsidies During the ICA. Agricultural Economics (United Kingdom), 43(SUPPL. 1), 19-32. https://doi.org/10.1111/j.15740862.2012.00617.x

Kamal, M. A., Khan, S., \& Gohar, N. (2020). Pakistan's Export Performance and Trade Potential in Central Asian Region: Analysis Based on Constant Market Share (CMS) and Stochastic Frontier Gravity Model. Journal of Public Affairs, 1, 1-11. https://doi.org/10.1002/pa.2254

Kuldilok, K. S., Dawson, P. J., \& Lingard, J. (2013). The export competitiveness of the Tuna industry in Thailand. British Food Journal, 115(3), 328-341. https://doi.org/10.1108/000707013113141 74

Mansion, S. E., \& Bausch, A. (2020). Intangible assets and SMEs' export behavior: a metaanalytical perspective. Small Business Economics, 55(3), 727-760. https://doi.org/10.1007/s11187-019-001825

Ministry of Foreign Affairs. (2020). Overview of Bilateral Relations Between Indonesia and Germany. https://kemlu.go.id/berlin/id/read/sekilashubungan-bilateral-indonesia-danjerman/1287/etc-menu 
Morris, J. (2010). Making Italian espresso. Food and History, 8(2), 155-183. https://doi.org/10.1484/j.food.1.102222

Nguyen, H. (2015). Empirical study of sustainable export coffee supply chain in Vietnam. International Journal of Business and Management, 10(7), 230-235. https://doi.org/10.5539/ijbm.v10n7p230

Nsabimana, A., \& Tirkaso, W. T. (2020). Examining Coffee Export Performance in Eastern and Southern African Countries: Do Bilateral Trade Relations Matter? Agrekon, 59(1), 46-64. https://doi.org/10.1080/03031853.2019.16 31864

Nugroho, A. D. (2021). Agricultural Market Information Services in Developing Countries: A Review. Agricultural Economics (Czech Republic), 67(11), 468477. www.ACSIJ.org

Osakwe, P. N., Santos-Paulino, A. U., \& Dogan, B. (2018). Trade dependence, liberalization, and exports diversification in developing countries 败. Journal of African Trade, 5(1-2), 19. https://doi.org/10.1016/j.joat.2018.09.001

Pascucci, F. (2018). The Export Competitiveness of Italian Coffee Roasting Industry. British Food Journal, 120(7), 1529-1546. https://doi.org/10.1108/BFJ-05-2017-0306

Petit, N. (2007). Ethiopia's Coffee Sector: A Bitter or Better Future? Journal of Agrarian Change, 7(2), 225-263. https://doi.org/10.1111/j.14710366.2007.00145.x

Rathgens, J., Gröschner, S., \& von Wehrden, H. (2020). Going beyond certificates: A systematic review of alternative trade arrangements in the global food sector. Journal of Cleaner Production, 276. https://doi.org/10.1016/j.jclepro.2020.1232 08

Ribeiro-Duthie, A. C., Gale, F., \& MurphyGregory, H. (2021). Fair trade and staple foods: A systematic review. Journal of Cleaner Production, 279, 123586. https://doi.org/10.1016/j.jclepro.2020.1235 86

Taj, Z. (2019). Evaluation of Afghanistan export performance : A analysis approach. Kardan
Journal of Economics and Management Sciences, November, 17-40. https://doi.org/10.31841/kar2019/2.2/2002

Torok, A., Mizik, T., \& Jambor, A. (2018). The Competitiveness of Global Coffee Trade. International Journal of Economics and Financial Issues, 8(5), 1-6.

Yifru, T. (2015). Impact of Agricultural Exports on Economic Growth in Ethiopia: The Case Of Coffee, Oilseed And Pulses. Egerto University.

Yu, Y., Feng, K., \& Hubacek, K. (2013). Teleconnecting local consumption to global land use. Global Environmental Change, 23(5), $1178-1186$. https://doi.org/10.1016/j.gloenvcha.2013.0 4.006 